\title{
The Moral Community and The Contestations of Politics in Thailand
}

\author{
Thannapat Jarernpanit \\ Faculty of Social Sciences \\ Chiang Mai University \\ Chiang Mai, Thailand \\ fugith@hotmail.com
}

\begin{abstract}
This paper focuses on the formation and transformation of moral community which refers to a unification of power, beliefs and emotions in the charismatic power of monarchy, and morality in religion that unite many Thais into a single community. Even though the Thai moral community has long been constructed and reproduced since the Siam modernnation state of 19th century, especially during the reign of King Rama IX. However, this paper argues that the Thai moral community had never been unified, it has frequently been faced with contestations from the challenges of the social sub-functions. This can be seen since the Siam modern-nation state period until the current Thai political conflicts and polarization, as witnessed during political conflicts among the yellow and red shirts, and the PDRC (the People's Democratic Reform Committee) over the last decade. Those has finally led to the struggles for power in the meaning of Thai politics and the challenges to the political and social order based on the hegemonic power of monarchy, moral politics and royal-nationalism discourse of Thailand, especially after the military coup of 2006 and 2014
\end{abstract}

Keywords—moral community; contestation; political meanings; yellow shirts; red shirts; PDRC

\section{INTRODUCTION}

The meaning of moral community refers to the characteristics of Thai political order and social order as well as Thai cultural identity based on the unification of morality and power, belief and emotion in the political ideology and communal relationship within the community centred by the hegemonic power of monarchy. The concepts that helped to construct the moral community are comprises of the HinduBuddhism as mandala, supernatural beings, magic power and supernatural mysterious power.

According to the concept of mandala, the King represented as the centre of state and surrounded by the state sub-systems. The King became a 'cakravatin' (universal monarch) or 'devarāja' (the god-king) according to his status and kingship in the circles of kings or mandala as the kingship of Khmer rulers during the early Southeast Asian political system. Notably, the King appeared as the 'the great man', 'man of prowess' or 'the big man' which means the extraordinary persons with qualities that distinguished them from others. This prowess signified and justified the spiritual and leadership resources of the King in the absolute status and being a person such a god-like [1, pp. 27, 112-113].
The Hindu-Buddhism concept describes the King as rajadharma or the moral King who follows the dhamma rules and acts as the maintainer of morality in the state and society. Thus, the state is governed by moral (dharma) and the ultimate purpose of the state is the moral purpose in Hindu-Buddhist doctrines. The King is considered the exemplary centre of the state and the highest good man (dhammaraja) according to his moral power. In this regard, the Hindu-Buddhism helped to legitimate power of the monarchy as the leader of Siamese state formation and the traditional Thai political structure centred on the monarchy. It provided a theoretical groundwork for the nature of royal power of the monarchy and the social order in moral hierarchy structure where the King is the superior moral power with his many merits accumulated. This can be found within the Hindu-Buddhist doctrine in the hierarchical cosmology of the Traiphuum. The Traiphuum was based on a correlation of ascending degrees of religious merits with higher levels of wisdom and heavenly existence. It provided a religious reflection and justification for the social hierarchy focused on the King [2, p. 52].

Subsequently, the Hindu-Buddhism helped to construct the reality of power of the monarchy especially the merit and sacred power. This power relation between people and monarchy in the hierarchy structure had been cascaded through communities within the Siamese state. Thai villages or communities were centred by the Buddhism, which was, therefore, served for legitimate power of the ruler in moral hierarchy structure. Significantly, a belief in Hindu-Buddhism has intertwined with a belief in supernatural beings (phi), magic power and supernatural mystical power of many Thai people. This can be seen in the spirit rituals and the rites of sacralisation of amulets, Buddha images and statues in Thai society. These rituals reflected a belief in sacred or supernatural power and charismatic power of Thais. Also, a belief in merit (bun or goodness) justified power and status of the King as the great man who has many merits accumulated in the Kingdom. Therefore, the beliefs in Hindu-Buddhism, supernatural beings and supernatural mystical power of Thais are supported a belief in charismatic and sacred power of the King. Meanwhile, the sacred rituals and beliefs in supernatural power became as a means of evoking the emotion and feelings associated with the moral order of Thai community [3, p. 102]. Accordingly, Thai moral community expresses itself like as 
the sacred and charismatic community centred by the kings who regarded as the highest merit or charismatic persons.

In addition, Buddhism is used as the state's tool for integration of all the state sub-functions into the common community of the Siamese state. Evidence can be seen from the reforming of Buddhist Sangha and the local monks conducted by the monarchy. As we shall see, the King Chulalongkorn (Rama IV: 1853-1910) reformed the Sangha or Dhammayuttika-Nikaya in 1833 and made the Siamese state and society to the Theravada Buddhism State [4]. It emphasized the royal Buddhism of the Thai court. The Buddhism reformation thus led to the development of a religious absolutism that paralleled and legitimated the political absolutism of the Thai monarchy in the second half of the nineteenth century [2, p. 46].

Hence, morality had been integrated with power of the monarchy and the formation of Thai state and society based on the Hindu-Buddhism concept and the beliefs in supernatural beings, magic power and supernatural mysterious power. Whilst Buddhism has been served for construction of the reality of the meaning of morality, it also justifies the moral hierarchy structure where the King is situated as the top of the structure and as the most virtuous being with superior morality. This is the reason why morality cannot be separated from the concepts of the King and state. In addition, it helps to constrain power in politics and societies.

This formation of the Siamese state and society in moral community concept is very important to understand the characteristics of Siamese modern-nation state in absolutist sovereignty of the King and the sacred state of Thailand, especially during the reign of King Rama 9. This formation significantly helped to construct the reality in nature of royal power of the monarchy in Thai politics, and the strong belief and perception of Thai people toward the morality and the monarchy as part of the social norm, political order and the state order. Notably, it helped to constitute and maintain the discourses of moral politics and royal-democracy in Thailand.

However, the problem is the embeddedness of moral community in the social construction of Thai society as a whole, which has never been unified and suppressed the diversity of thoughts, beliefs and emotions of many Thai people, as it represents the breaking-point for the sociocultural order of Thai moral community and politics. Those has finally led to the struggles for power among social subfunctions in the politics and Thai political order based on the hegemonic power of monarchy and royal-nationalism discourse of Thailand. Therefore, this paper aims to discuss how this formation of a moral community constituted, transformed and contested within the contexts of the Thai state and society. In particular, it focuses on the shifting of ideology, perception and emotion toward the moral community among many Thais during the contemporary Thai socio-political conflicts, especially after the military coup of 2006 and 2014.

\section{Research Methodology}

This research focuses on the documents research on study Thai political historical contexts, especially during the reign of King Rama 9, as the significant period of construction and transformation of Thai moral community. It is supported by the interpretation method and documentary resources from publications, newspapers, public statements, and memos of political protest groups from the military coup of 2006 to the military coup of 2014. Additionally, a literature review is provided on research studies, theses, reports and academic papers.

Besides, this research will use the individual interviews to interview those who had ever participated in the yellow shirt protests, the red shirt protests and the PDRC (the People's Democratic Reform Committee) movement from Chiang Mai and Bangkok by using semi - structured interview. Geographically these cities represent centers of political protests in each region of Thailand. The research focuses on both the yellow shirt, red shirt and PDRC supporters in each location, in order to reflect differences in perceptions, ideologies and emotions among them. Also, it shows the embeddedness and shifting of ideologies of Thai moral community centered on the monarchy among Thais.

\section{RESEARCH RESULTS}

\section{A. The Construction and Transformation of Thai moral community}

The construction and transformation of Thai moral community has long been inculcated in Thai historical contexts since the primeval period. Notably, it has distinctively been shaped during the King Bhumibol period (Rama IX: 1927 - 2016). The military coup of 1957 led by Field Marshall Sarit Thanarat, helped to reinstitute the monarchy insttution and the status of the King as the highest revered person of Thailand. As a reslt, the King (Rama IX) was seen as a symbol of the spirit of Thai people, Thai traditions, a source of social morality and ethics in the concept of Devine kinship, and a source of political legitimacy. As one can see, Sarit used the monarchy to legitimise his power and cultivate solidarity among the elites and social factions by social affairs, ceremonies and charity works. Meanwhile, he projected his image as the highest military successor. These were the domestic legitimizing functions in which the monarchy institution played the role of a legitimiser of political power in supporting the board regime policies, promoting and imposing sanctions in intra elite solidarity and becoming a symbolic of national unity [5].

In addition, the King played a crucial role in reconstitution of a moral community in Thai soceity. He stated that Thailand could not survive without a pure-of-practice dhammaraja, following the ten royal virtues. The dhammaraja is regarded as the ideal king for all Thais, while this position had to be held by a full Chakri or a man who carried the blood and spiritual inheritance of previous dhammarajas. This notion had been assimilated with the Thai political and social order. As we can see, the King possed both spiritual and secular 
power as the head of state and religious leader. Also, the King concluded that the politics and Western democratic government which adopted in the Siam revolution of 1932, created the conflict and disunity among Thais and hinnered the people's progress and development. It cannot create justice and peace in Thai society. The politics governed by the corrupt men is an inherently dirty and useless process, it cannot attract men of virtue and produce capable leaders. The best way to solve this problem is creating a good government under a sagacious soverign of the king to select the good men for leading the country [6, pp. 239-240]. This helped to establish the absolute power of the king in Thai politics and the royaldemocracy guilded by the king during and after the Sarit's era. On the other hand, the politics and democratic system were regarded as an immoral and inefficient political system governed by the corrupt and selfish politicians.

In the meantme, the publishing of the royal pictures helped to create the public understanding in the role and status of the monarchy as the highest revered institution and the King became as adored person for ordinary people. Notably, the charismatic power of the monarchy was considered very important in Thai political culture and in people's perception as it emphasized the order of a moral community among ordinary Thais. This is the great transformation of moral community in Thai political culture, politics and society because during and after this period, the King and Queen became like as the father and mother of the life of the nation. As one can see, the King's birthday had been celebrated as the new National Father's Day on 5 December 1980, while the Queen's birthday had been celebrated as the New National Mother's Day on 12 August 1976 [7, p. 7]. This had resulted in the strong belief and sentiment among Thais toward King Bhumibol as the father of all Thais and as the supreme extraordinary person (and King) of Thai nation. Also, it created the belief that the Thai nation would be maintained by the monarchy. All these clearly expressed in the hyperroyalism sentiment and political actions during the protests of the yellow shirt and PDRC protestors. It reflected the characteristic of Thai moral community as the social order and social force in the sentiments and actions of many Thais.

\section{B. The Impacts of Thai moral community on social and polticial order of Thailand}

The formation and transformation of the Thai moral community was resulted in the political legitimacy power in Thailand which had never been based on political consensus of communities, the democratic government and legal-rational institutions. The power is rather based on the cultural politics context, particularly in the charismatic power of the monarchy in the moral community. That is to say, good political leaders have to embody the goodness (charisma) of the monarchy. The political legitimacy can be acquired by the consent of people through their recognition and understanding in the goodness of the leaders where the King appears as the highest good man or the great man. The accountability of the leader equates with karmic merit and the role of the father which is a fundamental concept of Thais. This concept of leadership, power, and democracy is precisely different from the Western ideals and it has deeply embedded in Thai people's perception of the nation.

After the Sarit's regime, the monarchy absolutely held the position above politics in Thai public understanding. The monarchy positioned themselves as the moral authority superior to and on the top of the realm of normal politics, but not out of the political system. Meanwhile, the King became the source of political legitimacy and influenced the political ideal and issues. Importantly, the King played a crucial role in the political conflict during the student uprising on 14 October 1973 and guided the royal-democracy which is as an ostensibly democratic polity in which the electorate and elected authority do not have substantive power since true power remains in the hands of the monarchy after the 1973 [7]. The most significant element was embedded sentiment of royal the students, intellectuals and the urban middle class. Actually, it reflected the illusion in power of a moral community which was transformed within the royal-democracy and moral politics discourse. This perception has strongly remained in most Thais during the 21st century, especially during the political conflicts after the military coup of 2006.

\section{The Contestaions of Politics during the Contemporary Thai Political Conflicts}

The military coup of 2006 was launched by the Council for Democratic Reform under Constitutional Monarchy (CDRM) on 19 September 2006. They claimed that their action was to protect the monarchy institution and to bring peace and harmony back to Thai society. This showed the essence value and belief of the Thai moral community that the normal of Thai society is depended on the stability of monarchy. Meanwhile, it clearly showed a stark contrast between the moral politics ideal and the elected democracy. The crucial problem was that the political legitimacy and the formation of Thai state, political and social order were grounded in the moral community where the King is the only source of legitimacy power and centre of symbolic unity in Thai political culture. The idea of liberal democracy that focused on the efficiency and authority of elected democracy government was evidently not well supported in Thailand. This has eventually led to the political conflicts within Thai society arose from social and political groups demanding the constitution to be amended and anti-the military coup, and from the conflict that took place between the yellow shirt and red shirt groups.

The emergence of the red shirt movement's independent organization structures in several regions of the country led to the construction of a new social relationship and community network as well as the political perception and consciousness that did not integrate well with the socio-cultural structure and political order of the Thai moral community with the King at its centre. The dissemination of information within this group of communities, particularly on media and in political learning during the long protests, was very important for a construction of new political ideology and consciousness that deviated from the ideology and belief in moral community. Therefore, the development of the red shirts reflected changes in power relations, political perception and consciousness within rural 
Thai society, especially the new paradigm of the democratic system and ideal. Rural people had a better understanding of the democratic system; they knew they could negotiate and deal with state-government power. This was seen during Thaksin's government where rural subsidy policies were successfully launched.

Subsequently, the red shirt communities emerged as the new challenge to the order of moral community. These communities have differed by the diversification of beliefs, ideologies, emotions, values and interests according to the differences of experiences and positions of individuals, social classes and groups. Meanwhile, the ambiguous and unspeakable truth behind the military coup of 2006 and the military's violent suppression of the red shirt protests in 2010, accompanied by further suppression through the use of the Article 112 of Thai Criminal Code, led to a rapid loss of faith in the monarchy and to more questions arising within the hidden transcript of the ta sawanng ('knowing the truth') community of the red shirts. Thongchai [8] stated that ta sawanng communities were widespread across the country, especially among those from the lower income classes. These communities have continued to use anti-monarchy rhetoric, but using metaphors, codes, metonymical insinuation and a large number of allusions, those only understood by the communities themselves, and which do not cross into illegality under the lèse-majesté law [8, pp. 90-98].

The red shirt protests defended political society's direct transactions with power in all its regular and irregular forms, rejecting the view that economic development and other matters of state should be guided by the elite - members of which believe they are the embodiment of virtuous power located in the nation's capital [9, pp. 210-213]. According to them, their calls for justice and social equality were simply reflecting the word of democracy [10].

On the contrary, the meaning of democracy and politics from the middle class's perspectives who joined the yellow shirt and PDRC protests signified morality and the sense of class in the moral hierarchy structure of Thai political culture. Also, their desires for preserving their interests, their actions had been shaped and motivated by their moral mind. As a result, it cultivated the culture of fear and hate of Thaksin regime and the red shirts that they would topple the monarchy and destroy the nation and Thai society.

In my view, they hated Thaksin because his actions violated the normative moral standards and threatened their political and economic interests. Significantly, he violated the moral superiority and tried to replace the charismatic power of the King and the monarchy with the illegitimate power in their common-sense of experience. That is to say, the middle class viewed Thaksin as a demerit person (without a goodness or merit accumulated) when compared to the King (Rama 9). Thaksin was, therefore, considered illegitimate in the politics and became as a threat for the monarchy and the nation. This reflected the consequence of the moral community in which the legitimate power in Thai politics is based on the charismatic power of the monarchy in Thai cultural politics. Meanwhile, the feeling of hate and disgust were formed by the class bias sense within the Thai moral hierarchy structure. This ultimately led to a division between the middle class and the lower class, and a division between the urban group and rural group. Consequently, many urban middle class wanted the moral democracy which is based on the morality (in Buddhism) and the charismatic power (in merit and goodness) where the King (in personal) is the highest and a standard of righteousness. This can be argued that the urban middle class did not disregard democracy and an election in a democratic system as claimed by some scholars such as Tamada Yoshifumi [11] and Surachart Bamrongsuk [12]. However, they wanted the country to adopt the moral democracy which is legitimized by goodness and supported by the charismatic power of the monarchy.

\section{CONCLUSION}

The different meanings of politics among political protest supporters reflected the social disintegration and contestation of Thai political meaning and the political legitimacy of a moral community. For the yellow shirts and the PDRC supporters, the meaning of politics refers to the moral politics shaped by beliefs and emotions in the charismatic power of monarchy and morality in the Hindu-Buddhism. This became their political ideology and desire for the moral democracy based on the concepts of a good man and merit which actually reflected the ideal of royal-democracy and royal-nationalism in Thai political culture. They believed that the Thai democracy should be governed by morality and a good man, because it is righteousness and it can bring society to live in normal (prakati) with peace and harmony. For them, the goodness justifies the political legitimacy and becomes as the moral standard for all Thais.

On the other hand, the red shirt defined politics as it is closely linked to their everyday lives. The consequences of political learning and shared experiences and emotions among the red shirt protestors, had resulted in defining the meaning of politics in liberal democracy based on the rule of law, equality, justice and freedom. The red shirts viewed the Thai political legitimacy should come from the rule of law, a political consensus of people and an election in democratic system. These political meanings and sources of political legitimacy were contrasted to the political legitimacy of Thai political order based on the moral community.

Consequently, Thai politics faced with the problems of social disintegration in the meaning of politics and political legitimacy, as it could no longer create the common belief, emotion, ideology and legitimacy of a moral community in Thai political and social order. This found within the contestation of meanings of politics among the yellow shirt, red shirt and PDRC supporters, as the significant problem of a cleavage in Thai socio-political conflicts. This, in turn, reflected that the Thai moral community had never been united and was frequently faced with the contestations from the power struggles of social sub-functions. Hence, the crucial problem is the gap in understanding these political meanings and actions that the political demonstrators have applied during the contexts of political conflicts. 


\section{ACKNOWLEDGMENT}

I would like to express my sincere gratitude to my advisor, Yos Santasombat for his valuable guidance and suggestions in this research project. My sincere and deepest thanks also go to Tyrell Haberkorn for her endless support, helpful comments, and encouragement. I would like to say thank you to Suchart Setthamalinee, Chaiyan Rajhagool and Malinee Khumsupa for their academic supports and advices. I want to thank my colleagues in Faculty of Social Sciences, Chiang Mai University and Phibulsongkram Rajabhat University for various kinds of help. This research was supported by a scholarship from the Office of the Higher Education Commission, Ministry of Education, Thailand. Without this support, it would not be possible to conduct this research.

\section{REFERENCES}

[1] O. W. Wolters, History, culture, and region in Southeast Asian perspectives. New York: Southeast Asian Program, 1999.

[2] P. Jackson, Buddhism, legitimation, and conflict: The political functions of urban Thai Buddhism. Singapore: Institute of Southeast Asian Studies, 1989.

[3] S. Tanabe, "Ritual and Belief Systems: Anan Ganjanapan's Anthropological Political Economy,” in Kham Prom Dand Khawm Rue Hang Sangkomsart Thai [Transboundary of knowledge in Thai Social Sciences], P. Laungaramsri, W. Panyakaew and A. Siriphon, Eds., J. of Soc. Sci., Chiang Mai Univ., vol. 20, no. 2, pp. 95-114, 2008.
[4] S. Tanabe and C. Keyes, "Introduction," in Cultural crisis and social memory: modernity and identity in Thailand and Laos, S. Tanabe and C. F. Keyes, Eds. Honolulu: University of Hawaii Press, 2002, pp. 1-39.

[5] C. Thak, Thailand: The Politics of despotic paternalism. Bangkok: Silkworm books, 2007.

[6] P. M. Handley, The King Never Smiles: A Biography of Thailand's Bhumibol Adulyadej. New Haven, Connecticut: Yale University Press, 2006.

[7] W. Thongchai, Thailand's Hyper-royalism: Its Past Success and Present Predicament. Singapore: ISEAS Publishing, 2016.

[8] W. Thongchai, "The Monarchy and Anti-Monarchy: Two elephants in the room of Thai politics and the state of denial." in "Good Coup" Gone Bad: Thailand's Political Developments since Thaksin's downfall, Pavin Chachavalpongpun, Ed. Singapore: Institute of Southeast Asian Studies, 2014, pp. 79-108.

[9] A. Walker, "The political economy of Thailand's middle income peasants.” in Bangkok May 2010: Perspectives on a Divided Thailand, M. J. Montesano, P. Chachavalpongpun, and A. Chongvilaivan, Eds. Singapore: Institute of Southeast Asian Studies. 2012, pp. 323-332.

[10] C. Sopranzetti, "Burning red desires: Isan migrants and the politics of desire in contemporary Thailand.” S. E. Asia Res., vol. 20, no. 3, pp. 361-379, 2012.

[11] Prachathai, “ทามาดะ โยชิฟูมิ: การจับมือเป็นพันธมิตรกันของพลังต้าน ประชาธิปไตย [Tamada Yoshifumi: the alliance among the antidemocracy forces]," August 25, 2013. [Online]. Available: https://prachatai.com/journal/2013/08/48377.

[12] Matichon, “อ.จุฬาฯชี้ โจทย์ใหญ่เมืองไทย คือชนชั้นกลางไม่เอา ประชาธิปไตย [The lecturers of Chulalongkorn University issued the problem of Thailand is the middle class disregarded the democracy]," November 5, 2016. [Online]. Available: https://www.matichon.co.th/news/348709. 